\title{
Cohen syndrome
}

INSERM

\section{Source}

INSERM. (1999). Orphanet: an online rare disease and orphan drug data base. Cohen syndrome. ORPHA:193

Cohen syndrome (CS) is a rare genetic developmental disorder characterized by microcephaly, characteristic facial features, hypotonia, non-prog ressive intellectual deficit, myopia and retinal dystrophy, neutropenia and truncal obesity. 